\title{
Effect of Soaking with Yeast Solution on the Dormancy and Sprouting of Potato Tubers
}

\author{
${ }^{1}$ Dr. Rida DRAIE; ${ }^{2}$ Abdul-Mohsen AL-ALI \\ ${ }^{1}$ Faculty of Agricultural Engineering, University of Idlib, Syria \\ ${ }^{2}$ Postgraduate Student, MA, Faculty of Agricultural Engineering, University of Idlib, Syria
}

\begin{abstract}
The research was conducted with an aim of studying the behavior of the tubers of some potato varieties cultivated in northern Syria towards the dormancy and the sprouting. The research was carried out in the 2019 agricultural season in Idlib Governorate (AlRouj Plain), which is considered one of the most important potato production areas in Syria. Three varieties were used in the experiment: Spunta, Synergy, and Panela. The potato tubers were soaked with the yeast solution at four concentrations $(0,5,10$, and $20 \mathrm{~g} / \mathrm{L})$ during four different periods (0, 1, 2, and 3 hours). The design was used completely randomly (CRD) in the experiment with three replicates per treatment and each replicate was one $\mathrm{kg}$ tubers. The results showed the superiority of all treatments on the control and in all the studied characteristics. Where the treatment of the variety Spunta were superior in the studied traits, followed by the Panela, then Synergy. In addition, the highest concentration of the yeast solution (20 $\mathrm{g} / \mathrm{L}$ ) exceeded the other concentrations in the studied characters. Also, the longer soaking period (3 hours) outperformed the other soaking periods in the studied traits. Generally, the soaking of Spunta variety tubers with the yeast solution at $20 \mathrm{~g} / \mathrm{L}$ and the period of 3 hours gave the fastest break of the dormancy phase (25 days). While soaking the tubers of the Panela variety with yeast solution at the concentration of $20 \mathrm{~g} / \mathrm{L}$ and the period of 3 hours achieved the largest number of sprouts per tuber (1.60 sprouts). Whereas soaking the tubers of Synergy variety with the yeast solution of concentration of $20 \mathrm{~g} / \mathrm{L}$ and the period of 3 hours gave the highest weight of sprouts per sample (66.60 g).
\end{abstract}

Keywords: Potato, Tuber Dormancy, Sprouting, Yeast, Soaking.

\section{INTRODUCTION}

Potato is one of the main vegetable crops in the world, as it occupies an area of more than 20 million hectares distributed around the world, mainly in Europe, Asia and the Americas (FAO, 2019). In Syria, the cultivated area is estimated at 24 thousand hectares distributed mainly over the governorates of
Aleppo, Idlib and Hama, and fall cultivation constitutes more than $50 \%$ of the cultivated area and production (AASG, 2019).

After the crop has ripened and when the potato tubers (the reproductive units in potatoes) reach their final sizes, they enter a deep internal dormancy stage, during which their sprouts are not able to sprout even if the appropriate conditions are provided for them (Lang et al., 1987; Struik and Wiersema, 1999). This dormancy continues during the winter season and works to protect the tubers as members of vegetative reproduction under unfavorable conditions for growth. During this period, the tubers are very resistant to pathological injuries, and thus maintain their stocks of starch and protein for future sprouting (Ozeretskovskaya, 1990). During dormancy, biochemical and physiological processes take place but do not lead to morphological changes although these processes are related to the number of sprouts produced after breakage of the dormancy phase and the strength of their growth (Sukhova and Korableva, 1990). After the dormant period, the eyes of the tuber wake up and the sprouts begin to grow intensively with the formation of roots at their base. At this time, the tubers transform from a storage organ to a source of food and energy to secure the growth of sprouts (Struik, 2007). The dormancy period practically begins from the moment the shoots of the potato plant are mowed to the time when $80 \%$ of the tubers show sprouts of at least $2 \mathrm{~mm}$ in length (Van-Ittersum and Scholte, 1992).

The dormancy period usually ranges between 6-10 weeks, and the length of the period depends on the genetic factors (variety), and on the conditions associated with the growth stage of the tubers (Davidson, 1958; Wurr and Allen, 1976; Burton, 1978; Draie and Al-Absi, 2019b). The temperature, humidity and light period during growth and storage are important environmental factors that regulate the behavior of sprouting (Uwe, 2001; Ezekiel and Singh, 2003). The degree of maturity of the tubers upon harvesting, injuries caused by harvest or diseases, pests and treatment with internal and applied dormancy-breaking compounds also play a role on the length of the dormant period (Aksenova et al., 2013; Muthoni et al., 2014). Quantitative trait site analysis (QTL) showed that tuber dormancy is a quantitative genetic trait (Kotch et al., 1992) and is controlled by nine distinct chromosomal sites 
either independently or through overlapping interactions between them (Freyre et al., 1994; Ewing, 1995; Van-DenBerg et al., 1996).

Yeast is one of the types of biological fertilizers used in soil fertilization and foliar spraying of some vegetable crops and field crops (El-Ghamriny et al., 1999; Agamy et al., 2013). Yeast extract is a safe and non-polluting natural compound, containing many nutrients. Studies have shown that yeast is one of the richest sources of protein, the main amino acids such as lysine and tryptophan (Abou-Zaid, 1984), the main mineral elements and trace elements (calcium, phosphorous, nitrogen, potassium, magnesium, cobalt, iron), (Hesham and Mohamed, 2011). In addition to carbohydrates, reducing sugars, enzymes, and vitamin B groups (B1, B2, B6, B12), (Castel-Franco and Beale, 1983; Spencer et al., 1983; Somer, 1987; Fathy and Farid, 1996; Khedr and Farid, 2000). The yeast also contains the enzyme to synthesize the sugar trehalose 6-phosphate, which is an essential enzyme for the biological manufacture of trehalose sugar (Yeo et al., 2000). Yeast contains many nutrients and growth regulators such as auxins, gibberellins, and cytokinins (Ahmed, 1994; Glick, 1995; El-Ghamriny et al., 1999). Moreover, yeast is a natural source of cytokinins that cause cell division and elongation, and the synthesis of nucleic acids and chlorophylls (Kraig and Haber, 1980; Castel-Franco and Beale, 1983; Spencer et al 1983; Barnett et al., 1990; Fathy et al., 2000; Hewedy et al., 1996; Amer, 2004).

Several studies reported that foliar spraying with yeast solution to potato plants significantly improved both growth and yield in quantity and quality (Yeo et al., 2000; AbdelMouty et al., 2001; Awad, 2002; Mahmoud, 2004, Gomaa et al., 2005; Ahmed et al., 2013). The spraying with yeast gave a significant increase in plant height, number of tubers, stems and leaves /plant, yield/plant, total chlorophyll, T.S.S, tuber length and diameter, plant dry weight (Hussain and Khalaf, 2008; Sarhan and Abdullah, 2010; Ahmed et al., 2011;Lazim and Ahmed, 2013). El-Tohamy et al. (2008) found that spraying with yeast led to an increase in the cytokinin content of the treated plants, especially at a high concentration of yeast. El-Desuki and El-Gereadly(2006) indicated that foliar spraying with yeast increased the leaves content of photosynthetic pigments, carbohydrates, cytokinins, free amino acids, vegetative growth, quantity and quality of production, by increasing the concentration of the spraying solution from $1 \%$ to $3 \%$. In research done by Draie and AlAbsi (2019a) with the aim of studying the effect of treatment with yeast solution on the growth and productivity of potato crop, the combined treatment of soaking and foliar spraying outperformed all the studied characteristics of control plants and other treatments. Also, the treatment of foliar spraying with yeast solution in the yield/plant and in the yield/plot outperformed the control and the soaking treatment.

Given the importance of yeast and its various uses in the agricultural domain, in this paper we will examine the effect of soaking with the yeast solution (several concentrations and several periods) in breaking the dormancy of the tubers of some locally grown potato varieties.

\section{MATERIALS AND METHODS}

\subsection{Experimental Location}

The study was carried out in the agricultural season 2019, in Idlib countryside (Al-Rouj Plain region), where tubers were transferred after treatment to special rooms with low lighting and high humidity, with temperatures of about $25^{\circ} \mathrm{C}$.

\subsection{Plant Materials}

Three varieties are used in this research:

- Spunta: a medium early-ripening Danish variety, with elongated tubers, large size, smooth surface, short dormancy period and very shallow eyes.

- Panela: a fast-growing and ripening Dutch variety, the tubers are large elongated spherical.

- Synergy: a variety imported from a French company. Its tubers are elongated, medium to large size, with a medium dormancy period.

\subsection{Experimental Design and treatments}

The research was carried out on three varieties, which are Spunta, Synergy, and Panela. The tubers were treated with yeast solution at four concentrations $(0,5,10$, and $20 \mathrm{~g} / \mathrm{L})$ during four soaking periods ( $0,1,2$, and 3 hours). The complete randomized design (CRD) was used in the experiment with 3replicates per treatment and each replicate was one $\mathrm{kg}$ tubers. Consequently, the total number of treatments used in the experimentation $=3$ varieties $\mathrm{x} 4$ concentrations $\mathrm{x} 4$ soaking periods $\mathrm{x} 3$ replicates $=144$ treatments (144 $\mathrm{kg}$ potato tubers).

\subsection{Measured Parameters}

The following measurements were taken:

- The number of days until sprouting on tubers (length of dormancy).

- The number of sprouts on the tuber (sprouts per tuber).

- The number of sprouts on the sample (sprouts/1 kg tubers).

- The number of apical sprouts. 
ISSN (online): 2581-3048

- The number of basal sprouts.

- The daily growth rate of sprout $(\mathrm{cm})$.

- Average weight of one sprouts (g).

- Total weight of sprouts per tuber $(\mathrm{g})$.

- Weight of total sprouts per sample ( $\mathrm{g} / 1 \mathrm{~kg}$ tubers).

\subsection{Statistical analysis}

The results were analyzed by the statistical program (GenStat-12). The averages were compared by testing the least significant difference (LSD) at 5\% significance level.

\section{RESULTS AND DISCUSSION}

\subsection{Effect of one independent factor on the studied traits}

\subsubsection{Effect of the treatment with yeast}

Table (1): Effect of treatment with yeast on the studied traits

\begin{tabular}{|l|c|c|c|}
\hline \multicolumn{1}{|c|}{ Treatment } & Control & Yeast & LSD $_{0.05}$ \\
\hline Traits & $42.83^{\mathrm{b}}$ & $27.19^{\mathrm{b}}$ & 1.48 \\
\hline Days until sprouting & $0.63^{\mathrm{b}}$ & $1.19^{\mathrm{b}}$ & 0.24 \\
\hline Number of sprouts per tuber & $3.34^{\mathrm{b}}$ & $6.63^{\mathrm{b}}$ & 1.04 \\
\hline Number of sprouts per sample & $3.38^{\mathrm{b}}$ & $6.34^{\mathrm{b}}$ & 0.91 \\
\hline Number of apical sprouts & $0.08^{\mathrm{b}}$ & $0.29^{\mathrm{b}}$ & 0.42 \\
\hline Number of basal sprouts & $0.08^{\mathrm{b}}$ & $0.14^{\mathrm{a}}$ & 0.06 \\
\hline Daily growth rate of sprout $(\mathrm{cm})$ & $0.88^{\mathrm{b}}$ & $5.98^{\mathrm{a}}$ & 0.60 \\
\hline Average weight of one sprout $(\mathrm{g})$ & $1.46^{\mathrm{b}}$ & $7.23^{\mathrm{b}}$ & 1.13 \\
\hline Weight of sprouts per tuber $(\mathrm{g})$ & $4.32^{\mathrm{b}}$ & $39.77^{\mathrm{b}}$ & 7.50 \\
\hline Weight of total sprouts per sample & & & \\
\hline
\end{tabular}

The results of the statistical analysis in Table (1) showed that the treatment with the yeast was significantly superior to the control in all the studied traits, as the tubers began to sprout at 16 days in advance (27.19 days for the yeast treatments and 42.83 days for the control). The number of sprouts on the tuber increased by $88.8 \%$ (1.19 sprouts in the yeast treatments and 0.63 sprouts in the control), the number of sprouts per sample by $98.5 \%$ (6.63 sprouts in the yeast treatments and 3.34 sprouts in the control), the number of apical sprouts by $87.6 \%$ (6.34 sprouts in yeast treatments and 3.38 sprouts in control), and the number of basal sprouts increased by $262.5 \%$ ( 0.29 sprouts in yeast treatments and 0.08 sprouts in control). The daily growth rate increased by
$75 \%(0.14 \mathrm{~cm}$ in the yeast treatments and $0.08 \mathrm{~cm}$ in the control), the weight of one sprout increased by $579.5 \%(5.98 \mathrm{~g}$ in the yeast treatments and $0.88 \mathrm{~g}$ in the control), the weight of the sprouts on the tuber increased by $395 \%$ ( $7.23 \mathrm{~g}$ in the yeast treatments and $1.46 \mathrm{~g}$ in the control), and the weight of the sprouts per sample increased by $820.6 \%$ (39.77 $\mathrm{g}$ in the yeast treatments and $4.32 \mathrm{~g}$ in the control).

The previous results showed the importance of treatment with the yeast in improving most of the studied traits compared to the control, as the effect was evident in accelerating the sprouting of the tubers and breaking the dormancy phase early, and the number of sprouts per tubers increased and the rate of growth and development increased when treated with the yeast. These results are consistent with previous studies that showed that treatment with yeast solution of potato plants significantly improved both growth and production in terms of quantity and quality (Yeo et al., 2000; Abdel-Mouty et al., 2001; Awad, 2002; Mahmoud, 2004; Gomaa et al., 2005; Ahmed et al., 2013). The spraying with the yeast gave a significant increase in plant height, number of tubers, stems and leaves per plant, yield per plant, total chlorophyll, T.S.S, tuber length and diameter, plant dry weight (Hussain and Khalaf, 2008; Sarhan and Abdullah, 2010; Ahmed et al., 2011; Lazim and Ahmed, 2013). El-Tohamy et al. (2008) also found that spraying with yeast led to an increase in the cytokinin content of the treated plants, especially at a high concentration of yeast.El-Desuki and ElGereadly (2006) also indicated that foliar spraying with the yeast increased the leaves content of photosynthetic pigments, carbohydrates, cytokinins, free amino acids, vegetative growth, quantity and quality of production. In a research conducted by Draie and Al-Absi (2019a) with the aim of studying the effect of spraying with the yeast solution on the growth and productivity of the potato crop, the combined treatment of soaking and foliar spraying outperformed all the studied characteristics of control plants and other treatments. The attributes of yield / plant and yield / test lot on the control and on the soaking treatment. The treatment of foliar spraying with the yeast solution in the yield/plant and productivity/plot outperformed the control and the soaking treatment.

\subsubsection{Effect of the soaking period length}

Table (2): Effect of soaking period length on the studied traits

\begin{tabular}{|c|c|c|c|c|c|}
\hline $\begin{array}{l}\text { Soaking period length (hour) } \\
\text { Traits }\end{array}$ & $\mathbf{0}$ & 1 & 2 & 3 & $\mathbf{L S D}_{0.05}$ \\
\hline Days until sprouting & $42.83^{c}$ & $27.11^{b}$ & $26.31^{\mathrm{a}}$ & $26.22^{\mathrm{a}}$ & 0.70 \\
\hline Number of sprouts per tuber & $0.63^{c}$ & $1.15^{\mathrm{b}}$ & $1.38^{\mathrm{a}}$ & $1.47^{\mathrm{a}}$ & 0.10 \\
\hline Number of sprouts per sample & $3.34^{\mathrm{c}}$ & $6.66^{\mathrm{b}}$ & $7.91^{\mathrm{a}}$ & $8.33^{\mathrm{a}}$ & 0.53 \\
\hline Number of apical sprouts & $3.38^{\mathrm{d}}$ & $6.09^{c}$ & $7.14^{b}$ & $7.68^{\mathrm{a}}$ & 0.52 \\
\hline Number of basal sprouts & $0.08^{b}$ & $0.56^{\mathrm{a}}$ & $0.76^{\mathrm{a}}$ & $0.65^{\mathrm{a}}$ & 0.19 \\
\hline
\end{tabular}


ISSN (online): 2581-3048

Volume 5, Issue 4, pp 130-141, April-2021

https://doi.org/10.47001/IRJIET/2021.504020

\begin{tabular}{|l|l|l|l|l|l|}
\hline Daily growth rate of sprout $(\mathbf{c m})$ & $0.08^{\mathrm{b}}$ & $0.15^{\mathrm{a}}$ & $0.15^{\mathrm{a}}$ & $0.17^{\mathrm{a}}$ & 0.04 \\
\hline Average weight of one sprout $(\mathrm{g})$ & $0.88^{\mathrm{d}}$ & $4.90^{\mathrm{c}}$ & $5.39^{\mathrm{b}}$ & $5.86^{\mathrm{a}}$ & 0.28 \\
\hline Weight of sprouts per tuber $(\mathrm{g})$ & $1.46^{\mathrm{d}}$ & $5.74^{\mathrm{c}}$ & $7.50^{\mathrm{b}}$ & $8.71^{\mathrm{a}}$ & 0.60 \\
\hline Weight of total sprouts per sample & $4.32^{\mathrm{d}}$ & $32.10^{\mathrm{c}}$ & $40.66^{\mathrm{b}}$ & $47.42^{\mathrm{a}}$ & 3.75 \\
\hline
\end{tabular}

The results shown in Table (2) indicate that all treatment periods $(1,2$, and 3 hours) were significantly superior to the control ( 0 hour) in all the studied traits. The 3 -hour soaking period outperformed the other soaking periods in the number of apical sprouts with $7.68 \mathrm{~g}$, in the weight of one sprout with $5.86 \mathrm{~g}$, in the weight of the sprouts per tuber with $8.71 \mathrm{~g}$, and in the weight of the sprouts per sample with $47.42 \mathrm{~g}$. The 3hour soaking period and the 2-hour soaking period (Without significant differences between them) significantly exceeded the 1-hour soaking period in the number of days until sprouting with values of 26.22 days, 26.31 days, and 27.11 days respectively, in the number of sprouts per tuber with $1.47,1.38$, and 1.15 sprouts, respectively, in the number of sprouts per sample with values of $8.33,7.91$, and 6.66 sprouts, respectively. While there were no significant differences between the soaking periods of 3,2 and 1 hours in the number of basal sprouts (average of 0.66 buds) and the daily growth rate of sprout (an average of $0.16 \mathrm{~cm}$ ).

The previous results demonstrate the importance of all soaking periods in accelerating sprouting and breaking the dormancy phase. They reduced the dormant period by 17 days in the 3-hour period and the 2-hour period, and 16 days in the 1-hour period. Thus, the effect of the length of the treatment period was similar with respect to the dormancy of the tubers, but all the periods reduced the dormant period by a large time compared with control (43 days). These results are consistent with a number of studies that indicated an increase in the percentage of sprouting by increasing the length of treatment.

Draie and Al-Ali (2021) indicated that increasing the length of the treatment period led to faster sprouting of tubers and early breakage of the dormancy phase, and an increase in the number of sprouted shoots, and their daily growth rate and weight. Also, the longer soaking period gave the best results. Similarly, Radi et al. (2013) indicated that the percentage of sprouting increased with the length of the treatment period, and the longer period was the higher of the sprouting percentage. Al-Imam et al. (2016) also showed that increasing the length of the treatment period gave better results and led to an increase in sprouting percentage compared to the other treatments (shorter) and the treatment of the control. While, Al-Saadi (2013) stated that the increase in the length of the treatment period was counterproductive and caused a decrease in the sprouting percentage. These results can be explained by the fact that increasing the length of the treatment period leads to an increase in the sprouting percentage and improvement of the studied traits as long as this period falls below the critical limit, and in the event that the length of the treatment period exceeds the critical limit, it will lead to negative results on the studied traits.

\subsubsection{Effect of the treatment concentration}

Table (3): Effect of treatment concentration on the studied traits

\begin{tabular}{|l|c|c|c|c|c|}
\hline \multicolumn{1}{|c|}{ Concentration $(\mathrm{g} / \mathrm{L})$} & $\mathbf{0}$ & $\mathbf{5}$ & $\mathbf{1 0}$ & $\mathbf{2 0}$ & LSD $_{0.05}$ \\
\hline Traits & $42.83^{\mathrm{c}}$ & $27.56^{\mathrm{b}}$ & $26.44^{\mathrm{a}}$ & $25.64^{\mathrm{a}}$ & 0.87 \\
\hline Days until sprouting & $0.63^{\mathrm{d}}$ & $1.20^{\mathrm{c}}$ & $1.33^{\mathrm{b}}$ & $1.47^{\mathrm{a}}$ & 0.09 \\
\hline Number of sprouts per tuber & $3.34^{\mathrm{d}}$ & $7.04^{\mathrm{c}}$ & $7.72^{\mathrm{b}}$ & $8.15^{\mathrm{a}}$ & 0.42 \\
\hline Number of sprouts per sample & $3.38^{\mathrm{c}}$ & $6.50^{\mathrm{b}}$ & $7.05^{\mathrm{a}}$ & $7.36^{\mathrm{a}}$ & 0.44 \\
\hline Number of apical sprouts & $0.083^{\mathrm{b}}$ & $0.54^{\mathrm{a}}$ & $0.67^{\mathrm{a}}$ & $0.77^{\mathrm{a}}$ & 0.36 \\
\hline Number of basal sprouts & $0.081^{\mathrm{b}}$ & $0.15^{\mathrm{a}}$ & $0.15^{\mathrm{a}}$ & $0.16^{\mathrm{a}}$ & 0.04 \\
\hline Daily growth rate of sprout $(\mathrm{cm})$ & $0.88^{\mathrm{d}}$ & $4.74^{\mathrm{c}}$ & $5.38^{\mathrm{b}}$ & $6.04^{\mathrm{a}}$ & 0.29 \\
\hline Average weight of one sprout $(\mathrm{g})$ & $1.46^{\mathrm{d}}$ & $5.73^{\mathrm{c}}$ & $7.20^{\mathrm{b}}$ & $9.02^{\mathrm{a}}$ & 0.57 \\
\hline Weight of sprouts per tuber $(\mathrm{g})$ & $4.32^{\mathrm{d}}$ & $33.63^{\mathrm{c}}$ & $39.30^{\mathrm{b}}$ & $47.25^{\mathrm{a}}$ & 3.94 \\
\hline Weight of total sprouts per sample & & & & & \\
\hline
\end{tabular}

It appears from Table (3) that all the treatments of the concentrations $(5,10$, and $20 \mathrm{~g} / \mathrm{L})$ were significantly superior to the control $(0 \mathrm{~g} / \mathrm{L})$ in all the studied traits. The concentration of $20 \mathrm{~g} / \mathrm{L}$ significantly exceeded the other concentrations in the number of sprouts per tuber with 1.47 sprouts, in the number of sprouts per sample with 8.15 sprouts, in the weight of one sprout with $6.04 \mathrm{~g}$, in the weight of the sprouts per tuber with $9.02 \mathrm{~g}$, and in the weight of the sprouts per sample with $47.25 \mathrm{~g}$. The concentration of $20 \mathrm{~g} / \mathrm{L}$ and the concentration $10 \mathrm{~g} / \mathrm{L}$ significantly exceeded the concentration of $5 \mathrm{~g} / \mathrm{L}$ in the number of days until sprouting with values of 25.64 days, 26.44 days and 27.56 days, respectively, and in the number of apical sprouts with 7.36, 7.05 and 6.50 sprouts, respectively. While there were no significant differences 
ISSN (online): 2581-3048

between the concentrations 20,10 and $5 \mathrm{~g} / \mathrm{L}$ in the number of basal sprouts (average of 0.66 sprouts) and in the daily growth rate of sprout $(0.15 \mathrm{~cm}$ average $)$.

The previous results showed the positive effect of increasing the concentration in breaking the dormancy phase and accelerating the sprouting of tubers, as it led to a reduction of the dormant period by 17 days at $20 \mathrm{~g} / \mathrm{L}, 16$ days at $10 \mathrm{~g} / \mathrm{L}$, and 15 days at $5 \mathrm{~g} / \mathrm{L}$. These results are consistent with previous studies. Alam et al. (1994) showed that increasing the concentration of the treatment material leads to acceleration of sprouting and breaking the dormancy phase of the potato tubers without exceeding the critical level (which is the limit at which the negative effects of the treatment begin to appear). Also, Coleman and McIcerney (1997) and Coleman (1998) showed that higher concentrations were more effective and led to breaking-dormancy faster than lower concentrations. In a study conducted by Chindi and Tsegaw (2020), they showed that the higher concentrations were more influential on the studied traits. Draie and Al-Ali (2021) also showed that increasing the concentration of the treatment leads to faster tubers sprouting and early breakage of the dormancy phase, and that the higher concentration was more effective.

\subsubsection{Effect of the variety}

Table (4): Effect of the variety on the studied traits

\begin{tabular}{|l|c|c|c|c|}
\hline \multicolumn{1}{|c|}{ Variety } & Spunta & Synergy & Panela & LSD $_{0.05}$ \\
\hline Traits & $24.75^{\mathrm{a}}$ & $28.33^{\mathrm{c}}$ & $26.56^{\mathrm{b}}$ & 1.56 \\
\hline Days until sprouting & $1.65^{\mathrm{a}}$ & $1.06^{\mathrm{c}}$ & $1.29^{\mathrm{b}}$ & 0.23 \\
\hline Number of sprouts per tuber & $8.78^{\mathrm{a}}$ & $8.13^{\mathrm{a}}$ & $5.99^{\mathrm{b}}$ & 1.08 \\
\hline Number of sprouts per sample & $7.91^{\mathrm{a}}$ & $7.49^{\mathrm{a}}$ & $5.51^{\mathrm{b}}$ & 0.91 \\
\hline Number of apical sprouts & $0.87^{\mathrm{a}}$ & $0.63^{\mathrm{a}}$ & $0.48^{\mathrm{a}}$ & 0.43 \\
\hline Daily growth rate of sprout $(\mathrm{cm})$ & $0.19^{\mathrm{a}}$ & $0.13^{\mathrm{a}}$ & $0.15^{\mathrm{a}}$ & 0.06 \\
\hline Average weight of one sprout $(\mathrm{g})$ & $5.03^{\mathrm{b}}$ & $4.28^{\mathrm{c}}$ & $6.85^{\mathrm{a}}$ & 0.62 \\
\hline Weight of sprouts per tuber $(\mathrm{g})$ & $8.33^{\mathrm{a}}$ & $4.67^{\mathrm{b}}$ & $8.94^{\mathrm{a}}$ & 1.09 \\
\hline Weight of total sprouts per sample & $45.44^{\mathrm{a}}$ & $35.04^{\mathrm{b}}$ & $39.70^{\mathrm{a}, \mathrm{b}}$ & 7.67 \\
\hline
\end{tabular}

Table (4) shows the superiority of the Spunta variety in the number of days until sprouting, significantly over the Panela variety, which was significantly superior to the Synergy variety, as the sprouts appeared after 24.75, 26.56 and 28.33 days, respectively. Also, the Spunta variety was significantly superior in the number of sprouts per tuber, over the Panela variety, which was significantly superior on the Synergy variety. The number of sprouts per tuber was $1.65,1.29$ and 1.06, respectively. Table (1) shows the superiority of each of the two varieties, Spunta and Synergy, in the number of sprouts per sample, significantly over the variety Panela, with no significant differences between them, as the number of sprouts per sample was 8.78, 8.13 and 5.99 for the variety Spunta, Synergy, and Panela, respectively. Also, there were no differences between the two varieties, Spunta and Synergy, in the number of apical sprouts, and it was superior to the variety Panela, where the number of sprouts reached 7.91, 7.49 and 5.51 for the varieties Spunta, Synergy, and Panela respectively. There were no significant differences between the studied varieties in the number of basal sprouts per tuber, as the number of basal sprouts was $0.87,0.63$ and 0.48 for the varieties Spunta, Synergy, and Panela, respectively. Also, there were no significant differences between the studied varieties in the daily growth rate of sprouts, as the rate was
$0.19,0.15$ and $0.13 \mathrm{~cm} /$ day for the varieties Spunta, Panela and Synergy, respectively. Table (1) indicates the superiority of the variety Panela over the two varieties, Spunta and Synergy, as well as the superiority of the variety Spunta over the variety Synergy in the characteristic of sprout weight, as the sprout weight reached 5.03, 4.28 and $6.85 \mathrm{~g}$ for the varieties Spunta, Synergy and Panela respectively. The results of the statistical analysis according to Table (1) showed that the two varieties Spunta and Panela were significantly superior in the weight of sprouts per tuber over the variety Synergy (there were no significant differences between the two varieties Spunta and Panela), and the weights were 8.33, 4.67 and $8.94 \mathrm{~g}$ in the varieties Spunta, Synergy, and Panela respectively. Through Table (1), we notice the superiority of the Spunta variety over the Synergy variety the weight of the sprouts per sample, while there were no significant differences between the Spunta variety and the Panela variety on the one hand, and the Panela variety and Synergy on the other hand, and the weight of the sprouts per sample was 45.44, 35.04 and $39.70 \mathrm{~g}$ for the varieties Spunta, Synergy, and Panela, respectively.

Through the previous results, the effect of the genetic factor on the studied traits and parameters is evident, as the 
ISSN (online): 2581-3048

Spunta variety surpassed the other varieties, Synergy, and Panela, especially in the characteristic of dormancy-breaking and sprouting, as the dormancy in the Spunta variety ended two days before the Synergy variety and four days before the Panela variety despite applying the same treatments to all varieties. These results confirm the effect of the genetic factor on the dormancy of potato tubers and are consistent with previous studies that talked about the role of the genetic factor as one of the most important dormancy factors in tubers (Suttle, 2007; Muthoni et al., 2014). It also agrees with the findings of Nasiruddin et al. (2016) who showed the difference of the studied potato varieties among themselves in the dormancy period of the tubers and in the degree of the effect of the treatments in breaking the dormancy phase and in all the studied traits depending on the variety on which the treatment was applied. As for the size and weight of the tubers, and inversely proportional to the length of the dormant period (Krijthe, 1958; Suttle, 2007), our results were contrary to what was discussed in the aforementioned studies. Where the variety Spunta surpassed the two varieties Synergy and Panela despite the fact that the tubers are smaller and less weight. This can be explained and linked to the genetic factor, as the size of the tubers affects the length of the dormancy period when the tubers belong to the same variety and thus the degree of maturity (which is less in the young tubers) plays a role in the dormancy period, while in our case the smaller tubers belong to another variety that is characterized by a less dormant period (with the fact that these tubers have reached the stage of biological maturity), and therefore the differences in the dormancy period between the studied varieties are mainly due to the influence of the genetic factor.

\subsection{Effect of the interaction between the experimental factors on the studied traits}

\subsubsection{Number of days until sprouting}

Table (5): Effect of the interaction between the experimental factors on the number of days until sprouting

\begin{tabular}{|c|c|c|c|c|c|}
\hline $\begin{array}{l}\text { Treatmen } \\
\text { Period }\end{array}$ & $\mathrm{x}$ Con & $\begin{array}{l}\text { Variety } \\
\text { tion } x \\
\end{array}$ & Panela & Spunta & Synergy \\
\hline \multirow{9}{*}{ Yeast } & \multirow{3}{*}{$5 \mathrm{~g} / \mathrm{L}$} & $1 \mathrm{~h}$ & 28.00 & 27.00 & 28.00 \\
\hline & & $2 \mathrm{~h}$ & 27.00 & 26.00 & 28.00 \\
\hline & & $3 \mathrm{~h}$ & 27.00 & 26.00 & 28.00 \\
\hline & \multirow{3}{*}{$10 \mathrm{~g} / \mathrm{L}$} & $1 \mathrm{~h}$ & 27.00 & 26.00 & 28.00 \\
\hline & & $2 \mathrm{~h}$ & 27.00 & 26.00 & 28.00 \\
\hline & & $3 \mathrm{~h}$ & 27.00 & 26.00 & 28.00 \\
\hline & \multirow{3}{*}{$20 \mathrm{~g} / \mathrm{L}$} & $1 \mathrm{~h}$ & 26.00 & 26.00 & 28.00 \\
\hline & & $2 \mathrm{~h}$ & 26.00 & 25.00 & 27.00 \\
\hline & & $3 \mathrm{~h}$ & 26.00 & 25.00 & 27.00 \\
\hline \multirow{2}{*}{\multicolumn{3}{|c|}{$\frac{\text { LSD (5\%) }}{\text { C.V. }(\%)}$}} & \multicolumn{3}{|c|}{0.16} \\
\hline & & & \multicolumn{3}{|c|}{16.8} \\
\hline
\end{tabular}

The results of the statistical analysis of the interaction between the experimental factors outweigh the interaction of the Spunta variety with the concentration of $20 \mathrm{~g} / \mathrm{L}$ of the yeast solution within the periods of soaking 2 and 3 hours (there were no significant differences between the interaction of the periods of soaking 2 and 3 hours) in the breaking of dormant phase and sprouting, with an average 25 days after treatment, where the differences were significant, (Table 5).

\subsubsection{Number of sprouts per tuber}

Table (6): Effect of the interaction between the experimental factors on the number of sprouts per tuber

\begin{tabular}{|c|c|c|c|c|c|}
\hline \multicolumn{3}{|c|}{ Treatment $\mathrm{Y}$ Cariety } & \multirow[b]{2}{*}{ Panela } & \multirow[b]{2}{*}{ Spunta } & \multirow[b]{2}{*}{ Synergy } \\
\hline $\begin{array}{l}\text { Treatment } \\
\text { Period }\end{array}$ & $\bar{x}$ Cons & tion $x$ & & & \\
\hline \multirow{8}{*}{ Yeast } & \multirow{3}{*}{$5 \mathrm{~g} / \mathrm{L}$} & $1 \mathrm{~h}$ & 1.10 & 1.10 & 0.70 \\
\hline & & $2 \mathrm{~h}$ & 1.20 & 1.20 & 0.80 \\
\hline & & $3 \mathrm{~h}$ & 1.31 & 1.30 & 1.00 \\
\hline & \multirow{3}{*}{$10 \mathrm{~g} / \mathrm{L}$} & $1 \mathrm{~h}$ & 1.20 & 1.20 & 0.80 \\
\hline & & $2 \mathrm{~h}$ & 1.31 & 1.30 & 0.90 \\
\hline & & $3 \mathrm{~h}$ & 1.40 & 1.40 & 1.00 \\
\hline & \multirow{2}{*}{$20 \mathrm{~g} / \mathrm{L}$} & $1 \mathrm{~h}$ & 1.38 & 1.30 & 0.90 \\
\hline & & $2 \mathrm{~h}$ & 1.60 & 1.40 & 1.00 \\
\hline
\end{tabular}




\begin{tabular}{|c|c|c|c|c|}
\hline & $3 \mathrm{~h}$ & $\mathbf{1 . 6 0}$ & 1.50 & 1.20 \\
\hline LSD (5\%) & & $\mathbf{0 . 0 2 7}$ & \\
\hline C.V. (\%) & & $\mathbf{1 2 . 5}$ & \\
\hline
\end{tabular}

Table (6) shows the superiority of the interaction of the Panela variety with the $20 \mathrm{~g} / \mathrm{L}$ concentration of yeast solution within the periods of soaking 2 and 3 hours (there were no significant differences between the interaction of the periods of soaking 2 and 3 hours) in the number of sprouts per tuber with an average of 1.60 sprouts, where the differences were significant from the other interactions.

\subsubsection{Number of sprouts per sample}

Table (7): Effect of the interaction between the experimental factors on the number of sprouts per sample

\begin{tabular}{|c|c|c|c|c|c|}
\hline \multicolumn{3}{|c|}{$\begin{array}{l}\text { Treatment } x \text { Concentration } x \\
\text { Period }\end{array}$} & Panela & Spunta & Synergy \\
\hline \multirow{9}{*}{ Yeast } & \multirow{3}{*}{$5 \mathrm{~g} / \mathrm{L}$} & $1 \mathrm{~h}$ & 5.50 & 6.49 & 5.32 \\
\hline & & $2 \mathrm{~h}$ & 5.88 & 6.99 & 6.08 \\
\hline & & $3 \mathrm{~h}$ & 6.11 & 7.18 & 7.50 \\
\hline & \multirow{3}{*}{$10 \mathrm{~g} / \mathrm{L}$} & $1 \mathrm{~h}$ & 5.61 & 6.48 & 6.00 \\
\hline & & $2 \mathrm{~h}$ & 5.98 & 7.02 & 6.78 \\
\hline & & $3 \mathrm{~h}$ & 6.19 & 7.59 & 7.50 \\
\hline & \multirow{3}{*}{$20 \mathrm{~g} / \mathrm{L}$} & $1 \mathrm{~h}$ & 6.02 & 6.79 & 6.69 \\
\hline & & $2 \mathrm{~h}$ & 6.40 & 7.00 & 7.40 \\
\hline & & $3 \mathrm{~h}$ & 6.40 & 7.38 & 8.88 \\
\hline \multicolumn{3}{|c|}{ LSD (5\%) } & \multicolumn{3}{|c|}{0.058} \\
\hline \multicolumn{3}{|c|}{ C.V. $(\%)$} & \multicolumn{3}{|c|}{4.7} \\
\hline
\end{tabular}

Table (7) shows the superiority of the interaction of the Synergy variety with the $20 \mathrm{~g} / \mathrm{L}$ concentration of yeast solution within the 3-hour soaking period in the number of sprouts per weight unit (sample of one $\mathrm{kg}$ ) with an average of 8.88 sprouts, anywhere the differences were significant from the other interactions.

\subsubsection{Number of apical sprouts}

Table (8): Effect of the interaction between the experimental factors on the number of apical sprouts

\begin{tabular}{|c|c|c|c|c|c|}
\hline \multicolumn{3}{|c|}{$\begin{array}{l}\text { Treatment } x \text { Concentration } x \\
\text { Period }\end{array}$} & Panela & Spunta & Synergy \\
\hline \multirow{9}{*}{ Yeast } & \multirow{3}{*}{$5 \mathrm{~g} / \mathrm{L}$} & $1 \mathrm{~h}$ & 5.50 & 6.49 & 5.32 \\
\hline & & $2 \mathrm{~h}$ & 5.49 & 6.53 & 5.69 \\
\hline & & $3 \mathrm{~h}$ & 5.69 & 6.61 & 7.11 \\
\hline & \multirow{3}{*}{$10 \mathrm{~g} / \mathrm{L}$} & $1 \mathrm{~h}$ & 5.39 & 6.18 & 6.00 \\
\hline & & $2 \mathrm{~h}$ & 5.61 & 6.58 & 6.78 \\
\hline & & $3 \mathrm{~h}$ & 5.78 & 7.09 & 7.50 \\
\hline & \multirow{3}{*}{$20 \mathrm{~g} / \mathrm{L}$} & $1 \mathrm{~h}$ & 5.71 & 6.79 & 6.69 \\
\hline & & $2 \mathrm{~h}$ & 5.68 & 6.52 & 7.40 \\
\hline & & $3 \mathrm{~h}$ & 5.59 & 6.81 & 8.88 \\
\hline \multicolumn{3}{|c|}{ LSD (5\%) } & \multicolumn{3}{|c|}{0.035} \\
\hline \multicolumn{3}{|c|}{ C.V. $(\%)$} & \multicolumn{3}{|c|}{3.1} \\
\hline
\end{tabular}

The results in the Table (8) show the superiority of the interaction of the variety Synergy with the 20 g/L concentration of the yeast solution within the 3-hour soaking period in the number of apical sprouts, with an average of 8.88 sprouts, as the differences were significant from the other interactions.

\subsubsection{Number of basal sprouts}

Table (9): Effect of the interaction between the experimental factors on the number of basal sprouts

\begin{tabular}{r|r|r|r} 
Variety & Panela & Spunta & Synergy \\
\hline Treatment $x$ Concentration $x$ & Sy
\end{tabular}




\begin{tabular}{|c|c|c|c|c|c|}
\hline \multicolumn{6}{|l|}{ Period } \\
\hline \multirow{9}{*}{ Yeast } & \multirow{3}{*}{$5 \mathrm{~g} / \mathrm{L}$} & $1 \mathrm{~h}$ & 0.00 & 0.00 & 0.00 \\
\hline & & $2 \mathrm{~h}$ & 0.40 & 0.41 & 0.42 \\
\hline & & $3 \mathbf{h}$ & 0.41 & 0.50 & 0.36 \\
\hline & \multirow{3}{*}{$10 \mathrm{~g} / \mathrm{L}$} & $1 \mathrm{~h}$ & 0.29 & 0.30 & 0.00 \\
\hline & & $2 \mathrm{~h}$ & 0.32 & 0.41 & 0.00 \\
\hline & & $3 \mathrm{~h}$ & 0.40 & 0.50 & 0.00 \\
\hline & \multirow{3}{*}{$20 \mathrm{~g} / \mathrm{L}$} & $1 \mathrm{~h}$ & 0.30 & 0.00 & 0.00 \\
\hline & & $2 \mathrm{~h}$ & 0.78 & 0.48 & 0.00 \\
\hline & & $3 \mathrm{~h}$ & 0.81 & 0.52 & 0.00 \\
\hline & \multicolumn{2}{|c|}{ LSD (5\%) } & \multicolumn{3}{|c|}{0.035} \\
\hline & \multicolumn{2}{|c|}{ C.V. (\%) } & \multicolumn{3}{|c|}{3.1} \\
\hline
\end{tabular}

The results in the Table (9) show the superiority of the interaction of Panela variety with the 20 g/L concentration of yeast solution within the 3 -hour soaking period in the number of basal sprouts, with an average of 0.81 sprouts. The differences were significant from the other interactions.

3.2.6 Daily growth rate of sprout $(\mathrm{cm})$

Table (10): Effect of the interaction between the experimental factors on the daily growth rate of sprout

\begin{tabular}{|c|c|c|c|c|c|}
\hline \multicolumn{3}{|c|}{$\begin{array}{l}\text { Treatment } x \text { Cencentration } x \\
\text { Period }\end{array}$} & Panela & Spunta & Synergy \\
\hline \multirow{9}{*}{ Yeast } & \multirow{3}{*}{$5 \mathrm{~g} / \mathrm{L}$} & $1 \mathrm{~h}$ & 0.10 & 0.20 & 0.09 \\
\hline & & $2 \mathrm{~h}$ & 0.10 & 0.20 & 0.10 \\
\hline & & $3 \mathbf{h ~}$ & 0.10 & 0.20 & 0.10 \\
\hline & \multirow{3}{*}{$10 \mathrm{~g} / \mathrm{L}$} & $1 \mathrm{~h}$ & 0.10 & 0.20 & 0.10 \\
\hline & & $2 \mathrm{~h}$ & 0.10 & 0.20 & 0.10 \\
\hline & & $3 \mathrm{~h}$ & 0.20 & 0.20 & 0.10 \\
\hline & \multirow{3}{*}{$20 \mathrm{~g} / \mathrm{L}$} & $1 \mathrm{~h}$ & 0.10 & 0.20 & 0.10 \\
\hline & & $2 \mathrm{~h}$ & 0.10 & 0.20 & 0.10 \\
\hline & & $3 \mathrm{~h}$ & 0.20 & 0.30 & 0.10 \\
\hline \multicolumn{3}{|c|}{ LSD (5\%) } & \multicolumn{3}{|c|}{0.046} \\
\hline \multicolumn{3}{|c|}{ C.V. (\%) } & \multicolumn{3}{|c|}{29.8} \\
\hline
\end{tabular}

Table (10) shows the superiority of the interaction of the Spunta variety with the $20 \mathrm{~g} / \mathrm{L}$ concentration of yeast solution in the 3-hour soaking period in the daily growth rate of sprout, with an average of $0.30 \mathrm{~cm}$, wherever the differences were significant from the other interactions.

\subsubsection{Weight of one sprout $(g)$}

Table (11): Effect of the interaction between the experimental factors on the weight of one sprout (g)

\begin{tabular}{|c|c|c|c|c|c|}
\hline \multicolumn{3}{|c|}{$\begin{array}{l}\text { Treatment } x \text { Concentration } x \\
\text { Period }\end{array}$} & \multirow{2}{*}{$\begin{array}{c}\text { Panela } \\
5.30\end{array}$} & \multirow{2}{*}{$\begin{array}{c}\text { Spunta } \\
4.42\end{array}$} & \multirow{2}{*}{$\begin{array}{c}\text { Synergy } \\
4.51\end{array}$} \\
\hline \multirow{9}{*}{ Yeast } & \multirow{3}{*}{$5 \mathrm{~g} / \mathrm{L}$} & $1 \mathrm{~h}$ & & & \\
\hline & & $2 \mathrm{~h}$ & 6.50 & 4.69 & 4.60 \\
\hline & & $3 \mathrm{~h}$ & 7.10 & 5.10 & 4.80 \\
\hline & \multirow{3}{*}{$10 \mathrm{~g} / \mathrm{L}$} & $1 \mathrm{~h}$ & 5.60 & 4.78 & 5.50 \\
\hline & & $2 \mathrm{~h}$ & 6.70 & 5.49 & 6.20 \\
\hline & & $3 \mathrm{~h}$ & 7.40 & 5.88 & 7.50 \\
\hline & \multirow{3}{*}{$20 \mathrm{~g} / \mathrm{L}$} & $1 \mathrm{~h}$ & 5.90 & 5.18 & 5.50 \\
\hline & & $2 \mathrm{~h}$ & 7.10 & 6.68 & 6.90 \\
\hline & & $3 \mathrm{~h}$ & 7.80 & 6.80 & 7.50 \\
\hline \multicolumn{3}{|c|}{ LSD $(5 \%)$} & \multicolumn{3}{|c|}{0.043} \\
\hline \multicolumn{3}{|c|}{ C.V. $(\%)$} & \multicolumn{3}{|c|}{5} \\
\hline
\end{tabular}

The results in the Table (11) indicate the significant superiority of the interaction of Panela variety with the 20 g/L concentration of yeast solution within the 3 -hoursoaking period in the average weight of sprout by $7.80 \mathrm{~g}$, on all other interactions. 
Table (12): Effect of the interaction between the experimental factors on the weight of sprouts per tuber

\begin{tabular}{|c|c|c|c|c|c|}
\hline \multicolumn{3}{|c|}{ Variety } & \multirow[b]{2}{*}{ Panela } & \multirow[b]{2}{*}{ Spunta } & \multirow[b]{2}{*}{ Synergy } \\
\hline $\begin{array}{l}\text { Treatment } \\
\text { Period }\end{array}$ & $x$ Con & tion $x$ & & & \\
\hline \multirow{9}{*}{ Yeast } & \multirow{3}{*}{$5 \mathrm{~g} / \mathrm{L}$} & $1 \mathrm{~h}$ & 5.81 & 4.89 & 3.19 \\
\hline & & $2 \mathrm{~h}$ & 7.80 & 5.61 & 3.68 \\
\hline & & $3 \mathrm{~h}$ & 9.21 & 6.61 & 4.80 \\
\hline & \multirow{3}{*}{$10 \mathrm{~g} / \mathrm{L}$} & $1 \mathrm{~h}$ & 6.72 & 5.70 & 4.40 \\
\hline & & $2 \mathrm{~h}$ & 8.71 & 7.11 & 5.58 \\
\hline & & $3 \mathrm{~h}$ & 10.39 & 8.21 & 7.50 \\
\hline & \multirow{3}{*}{$20 \mathrm{~g} / \mathrm{L}$} & $1 \mathrm{~h}$ & 9.79 & 6.71 & 4.98 \\
\hline & & $2 \mathrm{~h}$ & 11.99 & 9.38 & 6.90 \\
\hline & & $3 \mathrm{~h}$ & 15.00 & 10.20 & 9.00 \\
\hline & \multicolumn{2}{|c|}{ LSD (5\%) } & \multicolumn{3}{|c|}{0.027} \\
\hline & \multicolumn{2}{|c|}{ C.V. $(\%)$} & \multicolumn{3}{|c|}{12.6} \\
\hline
\end{tabular}

The results in the Table (12) show the superiority of the interaction of the Panela variety with the $20 \mathrm{~g} / \mathrm{L}$ concentration of yeast solution within the 3-hoursoaking period in the weight of sprouts per tuber with an average of $14.42 \mathrm{~g}$. The superiority over the other interactions was significant.

\subsubsection{Weight of sprouts per sample}

Table (13): Effect of the interaction between the experimental factors on the weight of sprouts per sample

\begin{tabular}{|c|c|c|c|c|c|}
\hline \multicolumn{3}{|c|}{$\begin{array}{l}\text { Treatment } x \text { Concentration } x \\
\text { Period }\end{array}$} & Panela & Spunta & Synergy \\
\hline \multirow{9}{*}{ Yeast } & \multirow{3}{*}{$5 \mathrm{~g} / \mathrm{L}$} & $1 \mathrm{~h}$ & 29.18 & 28.69 & 24.02 \\
\hline & & $2 \mathrm{~h}$ & 38.22 & 32.68 & 27.99 \\
\hline & & $3 \mathrm{~h}$ & 43.38 & 36.49 & 36.00 \\
\hline & \multirow{3}{*}{$10 \mathrm{~g} / \mathrm{L}$} & $1 \mathrm{~h}$ & 31.51 & 30.78 & 33.00 \\
\hline & & $2 \mathrm{~h}$ & 40.09 & 38.59 & 41.88 \\
\hline & & $3 \mathrm{~h}$ & 45.58 & 42.79 & 56.28 \\
\hline & \multirow{3}{*}{$20 \mathrm{~g} / \mathrm{L}$} & $1 \mathrm{~h}$ & 35.52 & 34.99 & 36.61 \\
\hline & & $2 \mathrm{~h}$ & 45.41 & 46.78 & 51.09 \\
\hline & & $3 \mathrm{~h}$ & 49.92 & 49.98 & 66.60 \\
\hline \multicolumn{3}{|c|}{ LSD (5\%) } & \multicolumn{3}{|c|}{0.296} \\
\hline \multicolumn{3}{|c|}{ C.V. (\%) } & \multicolumn{3}{|c|}{1.5} \\
\hline
\end{tabular}

Table (13) displays the significant superiority of the interaction of the Synergy variety with the $20 \mathrm{~g} / \mathrm{L}$ concentration of yeast solution within the 3-hoursoaking period, in the weight of sprouts per weight unit (sample of one $\mathrm{kg}$ ) with an average of $99.00 \mathrm{~g}$.

The previous results show the importance of the interaction between the experimental factors in influencing the studied traits, whereas the Spunta variety treatments outperformed most of the studied traits (the effect of the genetic factor), the higher concentration treatments $(20 \mathrm{~g} / \mathrm{L})$, and the longer soaking period ( 3 hours) were superior in all the studied traits. We find that the interaction of the variety Spunta with the $20 \mathrm{~g} / \mathrm{L}$ concentration of yeast solution, the soaking periods of 2 and 3 hours (without significant differences between them) outperformed the other interactions in the sprouting velocity (shortest dormant period).Likewise, we find that the interaction of the variety Panela with the soaking period of 3 hours in yeast solution and the concentrations of 20 and $10 \mathrm{~g} / \mathrm{L}$ (without significant differences between them) outperformed the other interactions in the number of sprouts per tuber. While the interaction of Synergy variety with the concentration of $20 \mathrm{~g} / \mathrm{L}$ of yeast solution and the soaking period of 3 hours exceeded the other interactions in the number of sprouts per sample, in the number of the apical sprouts, and in the weight of sprouts per sample. Also, the interaction of Spunta variety with a concentration of $20 \mathrm{~g} / \mathrm{L}$ of yeast and the soaking period of 3 hours was the superior in the daily growth rate.

Our results coincide with many previous studies that showed the importance of the interaction of experimental factors in the studied traits, and dormancy and sprouting of potato tuber. El-Desuki and El-Gereadly (2006) showed the 
ISSN (online): 2581-3048

superiority of the interaction between the yeast solution with a higher concentration (3\%) over the other treatments, as it increased the leaf content of photosynthetic pigments, carbohydrates, cytokinins, free amino acids, vegetative growth, and the quantity and quality of the production. Also, El-Tohamy et al. (2008) found that the interaction between the yeast solutions with the higher concentration used led to an increase in the cytokinin content of the treated plants.

\section{CONCLUSION}

1) All treatments of soaking with yeast outperformed the control in all the studied characteristics, and led to breaking the dormant phase during a period of 27.19 days, while in the control it was 42.83 days.

2) The treatments of the Spunta variety exceeded the other treatments in the speed of breaking the dormancy phase ( 25 days), followed by the Panela variety (27 days), then the Synergy variety (28 days).

3) The concentration of $20 \mathrm{~g} / \mathrm{L}$ exceeded the other concentrations and led to breaking the dormancy phase within 26 days. Also, the 3-hour soaking period exceeded the other periods and led to breaking the dormancy phase within 26 days.

4) The soaking of Spunta variety tubers with the yeast solution at $20 \mathrm{~g} / \mathrm{L}$ and the period of 3 hours gave the fastest break of the dormancy phase (25 days), and the highest daily growth rate $(0.30 \mathrm{~cm} /$ day $)$. While soaking the tubers of the Panela variety with yeast solution at the concentration of $20 \mathrm{~g} / \mathrm{L}$ and the period of 3 hours achieved the largest number of sprouts per tuber (1.60 sprouts), the major number of basal sprouts (0.81 sprouts), the highest weight of one sprout $(7.80 \mathrm{~g})$, and the highest weight of sprouts per tuber $(15 \mathrm{~g})$. Whereas soaking the tubers of Synergy variety with the yeast solution of concentration of 20 $\mathrm{g} / \mathrm{L}$ and the period of 3 hours gave the highest number of sprouts per sample (8.88 sprouts), the highest number of apical sprouts ( 8.88 sprouts), and the highest weight of sprouts per sample $(66.60 \mathrm{~g})$.

\section{REFERENCES}

[1] AASG. (2019). Annual Agricultural Statistical Group. Directorate of Statistics and Planning, Ministry of Agriculture, Syria.

[2] Abdel-Mouty M.M.A, Ali H, Rizk F.A. (2001). Potato yield as affected by the interaction between bio and organic fertilizers. Egypt. J. Appl. Sci., 16(6): 267-286.

[3] Abou-Zaid M. (1984). Biochemical studies on fodder yeast. Ph. D. Thesis Fac. Agric. Cairo Univ. Egypt.
[4] Agamy R, Hashem M, AL-Amri S. (2013). Effect of soil amendment with yeasts as bio-fertilizers on the growth and productivity of sugar beet. African Journal of Agricultural Research, 8(1): 46-56

[5] Ahmed A.A, Abd El- Baky M.M.H, Helmy Y.I, Shafeek, M.R. (2013). Improvement of Potato Growth and Productivity by Application of Bread Yeast and Manganese. Journal of Applied Sciences Research, 9(8): 4896-4906.

[6] Ahmed A.A, Abd-El-Baky M.M.H, Zaki M.F, AbdEl-Aal F.S. (2011). Effect of foliar application of active extract and zinc on growth, yield and quality of potato plant (Solanum tuberosum L.). Journal of Applied Sciences Research, 7(12): 2479-2488.

[7] Ahmed A.A. (1994). Effect of some agricultural practices on potato production from seed tubers and seedling tubers. M.Sc. Thesis, Ain Shams Univ., pp: 100.

[8] Aksenova N.P, Sergeeva L.I, Konstantinova T.N, Golyanovskaya S.A, Kolachevskaya O.O, Romanov G.A. (2013). Regulation of Potato Tuber Dormancy and Sprouting. Russian Journal of Plant Physiology, 60(3): 301-312.

[9] Alam S.M.M, Murr D.P, Kristof L. (1994). The effect of ethylene and of inhibitors of protein and nucleic acid syntheses on dormancy break and subsequent sprout growth. Pot Res., 37: 25-33.

[10] Al-Imam N.M.A, Al-Allaf A.H, Shayal-alalam A.T. (2016). The effect of soaking periods with humic acid on improving seed germination and growth of Eriopotrya japonica seedlings. Al-Furat Journal of Agricultural Sciences, 8(3): 33-41.

[11] Al-Saadi N.J.J. (2013). The effect of some treatments on germination of Atropa belladonna seeds. Dyali Journal of Agricultural Sciences, 5(1): 230-235.

[12] Amer S.S.A. (2004). Growth, green pods yield and seeds yield of common bean (Phoseolus vulgaris L.) as affected by active dry yeast, salicylic acid and their interaction. J. Agric. Sci. Mansoura Univ., 29(3):1407-1422.

[13] Awad E.M. (2002). Effect of compost and some biofertilizers on growth, yield and quality of potato crops (Solanum tuberosum L.). J. Agric. Mansoura Univ., 27(8): 5525-5537.

[14] Barnett J.A, Payne R.W, Yarrow D. (1990). Yeast characteristics and identification. Cambradge. Camb. CBZBR, 40 west 20th. pp: 999.

[15] Burton W.G. (1978). The physics and physiology of storage. p. 545-606. In: Harris PM (ed) The potato crop. Chapman and Hall, London. 
ISSN (online): 2581-3048

[16] Castel-Franco P.A, Beale S.I. (1983). Chlorophyll biosynthesis recent advances and areas of current interest. Ann. Rev. Plant Physoil., 34: 241-278.

[17] Chindi A, Tsegaw T. (2020). Haulm application and dipping treatments of gibberellic acid on tuber dormancy breaking and sprout induction of potato (Solanum tuberosum L.) in Central Highlands of Ethiopia. International Journal of Plant Physiology and Biochemistry. 12(1): 1-8.

[18] Coleman W.K, Mclcerney J. (1997). Enhanced dormancy release and emergence from potato tubers. Ame Pot J., 74: 173-182.

[19] Coleman W.K. (1998). Carbon dioxide, oxygen and ethylene effects on potato tuber dormancy release and sprout growth. Annals Bot., 82: 21-27.

[20] Davidson T.M.V. (1958). Dormancy in the potato tuber and the effects of storage conditions on initial sprouting and on subsequent sprout growth. Ame Pot J., 35: 451-465.

[21] Draie R, Al-Absi M. (2019a). Effect of Bread Yeast Treatment on The Growth and Productivity of Potato Crop. International Journal of Information Research and Review, 06 (01): 6081-6085.

[22] Draie R, Al-Absi M. (2019b). Regulation and Control of Potato Tuber Dormancy and Sprouting. International Journal of Recent Advances in Multidisciplinary Research, 06(01): 4573-4583.

[23] Draie R, Al-Ali AM. (2021). Effect of Treatment with Gibberellic Acid on the Dormancy and Sprouting of Tubers of Some Potato Varieties. International Research Journal of Innovations in Engineering and Technology - IRJIET, 5(4): 97-107.

[24] El-Desuki M, El-Gereadly N.H.M. (2006). Response of pea plants to foliar application of yeast extract. J. Agric. Sci. Mansoura Univ., 31(10):6667-6674.

[25] El-Ghamriny E.A, Arisha H.M.E, Nour K.A. (1999). Studies in tomato flowering fruit set yield and quality in summer seasons. 1. Spring with thiamine, ascorbic acid and yeast. Zagazig J. Agric. Res., 26(5): 13451364.

[26] El-Tohamy W.A, El-Abagy H.M, El-Greadly N.H.M. (2008). Studies on the Effect of Putrescine, Yeast and Vitamin C on Growth, Yield and Physiological Responses of Eggplant Solanum melongena L. Under Sandy Soil Conditions. Australian Journal of Basic and Applied Sciences, 2(2): 296-300.

[27] Ewing E.E. (1995). The role of hormones in potato (Solanum tuberosum L.) tuberization. p. 698-724. In: Davies PJ (ed) Plant Hormones, Physiology, Biochemistry and Molecular Biology. Kluwer Academic Publication, Dordrecht.
[28] Ezekiel R, Singh B. (2003). Influence of relative humidity on weight loss in potato tubers stored at high temperatures. Indian J Plant Physiol., 8: 141144.

[29] FAO. (2019). Food and Agriculture Organisation of the United Nations. http://faostat.fao.org/ FAOSTAT: 2019.

[30] Fathy E.S.L, Farid S. (1996). The possibility of using vitamin $\mathrm{B}$ and yeast to delay senescence and improve growth and yield of common bean (Phaseolus vulgaris L.). J. Agric. Sci. Mansoura Univ., 21(4): 1415-1423.

[31] Freyre R, Warnke S, Sosinski B, Douches D.S. (1994). Quantitative trait locus analysis of tuber dormancy in diploid potato (SoIanum spp.). Theor Appl Gen., 89: 474-480.

[32] Glick B.R. (1995). The enhancement of plant growth by free living bacteria. Cand. J. Microbiology, 41: 109-117.

[33] Gomaa A.M, Moawad S.S, Ebadah I.M.A, Salim H.A. (2005). Application of bio-organic farming and its influence on certain pests infestation, growth and productivity of potato plants. Journal of Applied Sciences Research, 1(2): 205-211.

[34] Hesham A.L, Mohamed H. (2011). Molecular genetic identification of yeast strains isolated from Egyptian soils for solubilization of inorganic phosphates and growth promotion of corn plants. J. Microbiol. Biotechnol, 21:55-61.

[35] Hewedy A.M, Morsy M.A, Hafez M. (1996). Effect of frequency of fruit pickings and foliar spray with some stimulants on the subsequent seed yield of eggplant. Egypt-Hung-Hort- Conf., 1: 50-61.

[36] Hussain W.A, Khalaf L.Q. (2008). Some parameters of growth and productivity of potato crop after spraying with different concentrations of bread yeast. Journal of Al-Nahrain University - Science. 11(1): 33-37.

[37] Khedr Z.M.A, Farid S. (2000). Response of naturally virus infected tomato plant to yeast extract and phosphoric acid application. Annual of Agric. Sci. Moshtohor, 38(2): 927-939.

[38] Kotch G.P, Ortiz R, Peloquin S.J. (1992). Genetic analysis by use of potato haploid populations. Genome, 35: 103-108.

[39] Kraig E, Haber J.E. (1980). Messenger ribonucleic acid and protein metabolism during sporulation of saccharomyces cerevisiae J. Bacterial, 144: 10981112.

[40] Krijthe N. (1958). Changes in the germinating power of potatoes from the time of lifting onwards. Eur Pot J., 1: 69-72. 
ISSN (online): 2581-3048

[41] Lang G.A, Early J.D, Martin G.C, Darnell R.L. (1987). Endo-, para- and ecodormancy: Physiological terminology and classification for dormancy research. Hort Sci., 22: 371-377.

[42] Lazim Z.S, Ahmed Z.M. (2013). The effects spray applications of dry yeast suspension and liquorice root extractions on the vegetative and tubers growth characteristics of wild orchid Anacamptiscoriophora. Al-Furat Journal of Agricultural Sciences. 5(3): 2836.

[43] Mahmoud A.R. (2004). Response of potato to different level of organic nitrogen application and yeast spraying solution. Egypt. J. Appl. Sci., 19(11): 382-393.

[44] Muthoni J, Kabira J, Shimelis H, Melis R. (2014). Regulation of potato tuber dormancy: A review. Australian Journal of Crop Science, 8(5):754 -759.

[45] Nasiruddin M, Khatun R, Haydar F.M.A, Imtiaj A, Alam M.F. (2016). Effect of physical and chemical treatments on sprouting of dormant potato tubers. Plant Environment Development, 5(2):24-27.

[46] Ozeretskovskaya O.L. (1990). Cellular and Molecular Mechanisms of Immunity in Potato Plants, Regulyatsiyarostairazvitiyakartofelya (Regulation of Growth and Development in Potato Plants), Chailakhyan, M.Kh. and Mokronosov, A.T., Eds., Moscow: Nauka, pp. 131-137.

[47] Radi I.M, Kazem A.A, Safana H.S. (2013). Effect of type and duration of typesetting on seed germination and growth of apricot seedlings. Prunus armeniaca L. Muthanna Journal of Agricultural Sciences, 1(1): 6570 .

[48] Sarhan T, Abdullah O.K. (2010). Effects of Azotobacter Inoculation, Dry Bread Yeast Suspension and Varrying Levels of Urea on Growth of Potato cv. Desiree. http://www.tropentag.de/2010/abstracts/full/628.pdf

[49] Somer R. (1987). Yeast Production. HefeautolysateHerstellung. Eigenschafen und Anwendungen. BDLSpktrum 3, Bund Deutscher Lebens Mitel ev. RhenaniaFachveriag, Hamburg.

[50] Spencer T.F.T, Dorothy S.M, Smith A.R.W. (1983). Yeast genetics fundamental and applied aspects. Pp.
16-18. ISBNO-387-90973-9. Springer-Verlag New York, USA. Stuttgart, pp: 107-108.

[51] Struik P.C, Wiersema S.G. (1999). Seed potato technology. Wageningen University Press. The Netherlands.

[52] Struik P.C. (2007). Above-Ground and BelowGround Plant Development, Potato Biology and Biotechnology: Advances and Perspectives, Vreugdenhil, D., Ed., Amsterdam: Elsevier, pp. 219236.

[53] Sukhova L.S, Korableva N.P. (1990). Regulation of Potato Tuber Dormancy and Their Resistance to Diseases via Hormonal Balance Modified by Ethylene Donors, Regulyatsiyarostairazvitiyakartofelya (Regulation of Growth and Development of Potato Plants), Chailakhyan, M.Kh. and Mokronosov, A.T., Eds., Moscow: Nauka, pp. 138-142.

[54] Suttle J.C. (2007). Dormancy and Sprouting, Potato Biology and Biotechnology: Advances and Perspectives, Vreugdenhil, D., Ed., Amsterdam: Elsevier, pp. 287-309.

[55] Uwe S. (2001). Control of potato tuber sprouting. Trends in Plant Science, 6: 333-335.

[56] Van-Den-Berg J.H, Ewing E.E, Plaisted R.L, McMurray S, Bonierbale M.W. (1996). QTL analysis of potato tuber dormancy. Theor Appl Gen., 93: 317324.

[57] Van-Ittersum M.K, Scholte K. (1992). Relation between growth conditions and dormancy of seed potatoes. 2. Effects of temperature. Pot Res., 35: 365375 .

[58] Wurr D.C.E, Allen E.J. (1976). Effects of cold treatments on the sprout growth of three potato varieties. J Agric Sci. (Cambridge), 86: 221-224.

[59] Yeo E, Hawk-Bin K, Sang-Eum H, Joon-Tak L, JinChang R, Myung-Ok B, Yeo E.T, Kwon H.B, Han S.E, Lee J.T, Ryu J.C, Byun M.O. (2000). Genetic engineering of drought resistant potato plants by introduction of the trehalose-6-phosphatsynthase (TPSI) gene from Saccharomyces cerevisiae. Molecules and Cells, 10(3): 263-268.

\section{Citation of this Article:}

Dr. Rida DRAIE; Abdul-Mohsen AL-ALI, "Effect of Soaking with Yeast Solution on the Dormancy and Sprouting of Potato Tubers" Published in International Research Journal of Innovations in Engineering and Technology - IRJIET, Volume 5, Issue 4, pp 130-141, April 2021. Article DOI https://doi.org/10.47001/IRJIET/2021.504020 